\title{
PENEGAKAN HUKUM DAN HAK ASASI MANUSIA DENGAN PARADIGMA PANCASILA TERHADAP TINDAKAN PENOLAKAN PEMAKAMAN JENAZAH KORBAN COVID - 19
}

\author{
Marthin Fransisco Manihuruk \\ ${ }^{1)}$ Universitas HKBP Nommensen Pematangsiantar
}

\begin{abstract}
This study discusses the influence of law enforcement with the paradigm of Pancasila in addressing the action of the funeral of the dead bodies exposed to Covid-19. Rejection of the funeral of the body of the victim Covid-19 is contrary to the perspective of the law and also Pancasila. Law No. 4 of 1984 on the infectious disease outbreak clearly said that the act of disrupting the plague prevention efforts was contrary to the law and imposed criminal sanctions. While from the perspective of Pancasila, it can be seen that the funeral rejection Act Covid - 19, including into acts contrary to the values of Pancasila. Apart from being an ideology of state, Pancasila is also the source of any source of law of the country as listed in article 2 of the Law number 12 year 2011 concerning the establishment of legislation. The disapproval of the funeral of the Covid-19 bodies is contrary to the law and human rights as contained in Indonesia's legislation as in the Universal Declaration of Human Rights, the International Covenant on Civil and Political Rights. The influence of law enforcement is certainly a very important factor in the enforcement and strengthening of values that correspond to the paradigm of Pancasila.
\end{abstract}

Keywords: Law enforcement, human rights, Covid-19

\begin{abstract}
ABSTRAK
Penelitian ini membahas tentang Pengaruh Penegakan Hukum dengan Paradigma Pancasila dalam menyikapi tindak penolakan Pemakaman Jenazah yang terpapar Covid -19. Tindakan penolakan Pemakaman jenazah dari korban Covid - 19 merupakan hal yang bertentangan dari perspektif hukum dan juga Pancasila. Undang-undang Nomor 4 tahun 1984 tentang Wabah Penyakit Menular jelas mengatakan bahwa tindakan yang mengganggu upaya penanggulangan wabah adalah bertentangan dengan hukum dan dikenakan sanksi Pidana. Sedangkan dari perspektif Pancasila dapat dilihat bahwa Tindakan Penolakan Pemakaman Jenazah Covid - 19, termasuk ke dalam perbuatan yang bertentangan dengan nilai-nilai Pancasila. Selain sebagai Ideologi negara, Pancasila juga merupakan sumber dari segala sumber Hukum negara seperti yang tercantum di dalam pasal 2 Undang-undang Nomor 12 Tahun 2011 tentang Pembentukan Peraturan Perundangundangan. Tindakan penolakan pemakaman jenazah Covid -19 merupakan perbuatan yang bertentangan dengan Hukum dan Hak Asasi manusia sebagaimana yang terdapat di dalam Peraturan Perundang-undangan di Indonesia seperti di dalam Deklarasi
\end{abstract}


universal hak asasi manusia, kovenan internasional hak-hak sipil dan politik. Pengaruh penegakan Hukum tentunya menjadi faktor yang sangat penting dalam penegakan dan penguatan kembali nilai-nilai yang sesuai dengan paradigma Pancasila.

Kata Kunci: Penegakan Hukum, Hak Asasi Manusia, Covid-19

\section{PENDAHULUAN}

Menurut Miriam Budiardjo, Negara adalah suatu organisasi dalam suatu wilayah yang memiliki kekuasaan tertinggi yang sah dan ditaati oleh rakyatnya (Budiardjo, 2008:17). Salah satu unsur mutlak dari sebuah negara adalah rakyat/masyarakat. Indonesia terdiri dari berbagai unsur atau elemen masyarakat yang berbeda-beda. Elemen masyarakat yang berbeda-beda itu didasarkan pada suku, agama, ras, budaya dan yang lainnya. Perbedaan dari elemen masyarakat ini, tentu akan membawa cara pandang yang berbeda yang dipengaruhi oleh suku, agama, ras, budaya dan yang lainnya dalam menyikapi sebuah masalah. Perbedaan cara pandang di dalam masyarakat tentunya tidak boleh bertentangan dengan aturan-aturan yang telah ditetapkan. Perbedaan cara pandang masyarakat Indonesia, tetap harus sesuai dengan nilai-nilai yang terdapat dalam Pancasila.

Kajian tentang masyarakat sebagai suatu komponen dari sebuah Negara, maka akan mengkaji Sosiologi sebagai suatu ilmu yang menganalisis aspek sosial yang terdapat di dalam kehidupan masyarakat. Masyarakat merupakan objek kajian sosiologi. Objek kajian sosiologi dapat diamati dari hubungan antarmanusia (interaksi sosial) beserta sebab dan akibatnya. Atas dasar interaksi sosial dan kesamaan yang mengatur manusia ( nilai dan norma sosial) dalam suatu kelompok, sosiologi tidak mempelajari manusia sebagai Individu, tetapi sebagai makhluk sosial (Kusumantoro, 2019:5). Sosiologi menganggap negara sebagai salah satu lembaga pengendalian sosial (agent of social control). Sosiologi menggambarkan bahwa pada masyarakat yang sederhana maupun yang kompleks senantiasa terdapat kecenderungan untuk timbulnya proses, pengaturan, atau pola-pola pengendalian tertentu yang formal maupun tidak formal (Budiardjo, 2008:29).

Penelitian ini mengkaji kasus tindakan penolakan yang dilakukan oleh sekelompok warga/ masyarakat terhadap pelaksanaan pemakaman jenazah Covid-19 secara Normatif. Alasan yang mendasar terjadinya Tindakan Penolakan Pemakaman Jenazah Covid - 19 ini bahwa tidak adanya sosialisasi terhadap warga sekitar dan adanya kekhawatiran terjadi penularan virus Covid-19 yang berasal dari jenazah Covid - 19 kepada warga masyarakat sekitar yang tinggal di sekitar pemakaman ataupun dekat dengan tempat pemakaman tersebut. Akan tetapi, telah terjadi persepsi yang salah terhadap jenazah korban Covid-19 tersebut. Persepsi itu tentunya dipengaruhi oleh banyak faktor diantaranya adalah faktor kurangnya sosialisasi, lingkungan dan Pengetahuan masyarakat terhadap hal-hal yang berkaitan dengan Covid19. Permasalahan-permasalahan seperti ini akan berimplikasi kepada masalah

41 | Penegakan hukum dan hak asasi manusia.. Manihuruk, Marthin Fransisco

Jurnal Christian Humanioran | http://e-journal.iakntarutung.ac.id/index.php/humaniora 
kemanusiaan. Masalah kemanusiaan akan berkaitan dengan masalah Pancasila, Kesadaran Hukum, pengetahuan dan lingkungan. Dasar Permasalahan di dalam Penelitian ini adalah adanya pelanggaran Hukum dan Hak Asasi manusia diakibatkan dari tindakan penolakan Pemakaman jenazah Covid -19 dan dikaitkan dengan perspektif keadilan terhadap kemanusiaan. Pentingnya kesadaran akan keadilan dan kemanusiaan harus dipahami setiap elemen masyarakat. Karena manusia itu makhluk budaya, perlakuan kepada sesama manusia juga berbudaya dan beradab. Perlakuan beradab adalah perlakuan adil, artinya perlakuan kepada pihak lain juga seperti perlakuan kepada diri sendiri (Muhammad, 2011:176).

\section{Rumusan Masalah}

Adapun masalah dalam penelitian ini adalah:

1. Bagaimanakah Penegakan Hukum dan Hak Asasi Manusia terhadap tindakan penolakan Pemakaman jenazah korban Covid-19?

2. Bagaimanakan Penegakan Hukum dan Hak Asasi Manusia dilakukan dengan Paradigma Pancasila dalam upaya pencegahan penolakan pemakaman Jenazah korban Covid-19?

\section{Tujuan Penelitian}

1. Untuk mengetahui Penegakan Hukum dan Hak Asasi Manusia yang harus dilakukan berdasarkan peraturan perundang-undangan dalam menangani tindakan penolakan pemakaman jenazah korban Covid-19

2. Untuk mengetahui Penegakan Hukum dan Hak Asasi Manusia dengan Paradigma Pancasila dalam upaya melakukan Pencegahan Penolakan Pemakaman Jenazah korban Covid-19.

\section{Metode Penelitian}

Penelitian ini dilakukan dengan metode Penelitian Normatif. Metode penelitian Normatif disebut juga penelitian hukum Doktrinal. Penelitian Hukum Doktrinal dibagi menjadi 3 bagian yaitu (Ibrahim \& Johnny, 2016):

1. Penelitian Hukum Doktrinal yang mengkaji hukum yang dikonsepkan sebagai asas hukum alam dalam sistem moral menurut doktrin hukum alam

2. Penelitian Doktrinal yang mengkaji hukum yang dikonsepkan sebagai kaidah perundang-undangan menurut doktrin positivis

3. Penelitian Doktrinal yang mengkaji hukum yang dikonsepkan sebagai keputusan hakim in concreto menurut doktrin realism.

Metode penelitian Normatif digunakan untuk menganalisis produk-produk hukum yang berkaitan dengan penanganan wabah menular dan produk hukum yang menyangkut dengan Penegakan Hukum dan Hak Asasi Manusia, serta mengkaji Produk-produk hukum tersebut untuk melihat kesesuaian nya dengan Paradigma Pancasila. 


\section{PEMBAHASAN}

\section{Penegakan Hukum dan Hak Asasi Manusia}

Menurut Miriam Budiardjo (2008:211), Hak Asasi Manusia biasanya dianggap sebagai hak yang dimiliki setiap manusia, yang melekat atau inheren padanya karena dia adalah manusia. Setiap manusia pada hakikatnya mempunyai Hak Asasi yang melekat pada dirinya. Pasal 1 angka 1 Undangundang Nomor 39 tahun 1999 tentang Hak Asasi Manusia menyebutkan bahwa Hak Asasi Manusia adalah seperangkat Hak yang melekat pada hakikat dan keberadaan manusia sebagai Makhluk Tuhan Yang Maha Esa dan merupakan Anugerah-Nya yang wajib dihormati, dijunjung tinggi dan dilindungi oleh negara, hukum dan pemerintah, dan setiap orang demi kehormatan serta perlindungan harkat dan martabat manusia (Pasal 1 Angka 1 Undang-undang Nomor 39 tahun 1999 tentang Hak Asasi Manusia). Perlindungan Hak Asasi Manusia ini tentunya dilindungi dengan instrumen hukum positif. Hukum positif tentu bertujuan untuk memberikan kepastian hukum bagi seluruh elemen masyarakat. Hukum positif yang berupa peraturan perundangundangan yang berlaku di Indonesia, haruslah didasarkan dengan semangat dan nilai Pancasila. Inilah sebabnya Pancasila dikatakan sebagai Philosofische Grondslag, yang berarti bahwa Pancasila merupakan sumber dari segala sumber hukum yang ada di Indonesia. Maka penerapan peraturan perundangundangan harus menjadikan kehidupan bermasyarakat, berbangsa dan bernegara sesuai dengan kaidah-kaidah Pancasila.

Tindakan penolakan pemakaman jenazah Covid - 19, maka haruslah dikaji dari perspektif Hukum dan perspektif Hak Asasi Manusia. Pelaksanaan penegakan Hukum dan Hak Asasi Manusia, menjadi unsur utama dalam memberikan keadilan. Hukum dikatakan sebagai rekayasa sosial ( law as a tool of social engineering) sebagaimana dikemukakan oleh Roscoe Pound. Dalam mencapai fungsi hukum sebagai rekayasa sosial (masyarakat) ke arah yang lebih baik, maka bukan hanya ketersediaan hukum/peraturan yang dibutuhkan, tetapi juga jaminan atas perwujudan kaidah hukum tersebut ke dalam praktek hukum atau dengan kata lain adanya Penegakan Hukum ( Law enforcement) yang baik (Fuady, 2018:40). Memberikan keadilan di dalam penegakan hukum, maka harus dilihat dari pelaksanaan hukum positif. Pasal 6 International Covenant on Civil and Political Rights ( ICCPR), mengatakan bahwa " setiap manusia berhak atas hak untuk hidup yang melekat pada dirinya. Hak ini wajib dilindungi oleh hukum. Tidak seorang pun dapat dirampas hak hidupnya secara sewenang-wenang (International Covenant on Civil and Political Rights). Maka dalam hal ini, harus dilakukan penegakan hukum oleh aparat penegakan hukum supaya tidak terjadi pelanggaran terhadap hak-hak dasar manusia. International Covenant on Civil and Political Rights sudah diratifikasi melalui Undang-undang Nomor 12 Tahun 2005. Sehingga dalam hal ini, tindakan penolakan pemakaman jenazah korban Covid-19, bertentangan dengan ICCPR. Oleh karena itu, agar Hak Asasi Manusia terjamin, maka harus dilaksanakan penegakan hukum melalui instrumen hukum. Soerjono Soekanto dalam Munir Fuady mengatakan bahwa 
ada beberapa faktor yang mempengaruhi penegakan hukum yaitu (Fuady, 2018:46):

1. Faktor Hukumnya Sendiri ( termasuk faktor undang-undang)

2. Faktor Penegak Hukum ( dimasukkan disini baik para pembentuk maupun penerap hukum)

3. Faktor Sarana atau Fasilitas yang mendukung penegakan hukum

4. Faktor Masyarakat, yakni masyarakat dimana hukum tersebut diterapkan

5. Faktor kebudayaan, yakni sebagai hasil karya, cipta, dan karsa yang didasarkan pada karsa manusia di dalam pergaulan hidup.

Penegakan hukum harus mencapai tujuan hukum itu sendiri. Tujuan hukum seperti yang dikemukakan Gustav Radbruch, yaitu Keadilan, Kepastian, dan Kemanfaatan. Tujuan hukum tersebut haruslah menjiwai setiap penegakan hukum di Indonesia yang diimplementasikan di dalam perundang-undangan. Upaya penanggulangan wabah Covid-19 yang dilakukan pemerintah dilakukan sesuai dengan peraturan Perundangundangan. Pasal 5 ayat (1) huruf e Undang-undang Nomor 4 Tahun 1984 tentang Wabah Penyakit Menular (Undang-undang Nomor 14 tahun 1984 tentang Penyakit Wabah Menular. Penjelasan Pasal 5 mengatakan bahwa upaya penanggulangan wabah mempunyai 2 tujuan pokok yaitu : (1). Berusaha memperkecil angka kematian akibat wabah dengan pengobatan; (2). Membatasi penularan dan penyebaran penyakit agar penderita tidak bertambah banyak, dan wabah tidak meluas kedaerah lain), mengatakan bahwa upaya penanggulangan wabah meliputi :(a). Penyelidikan Epidemiologis; (b) Pemeriksaan, pengobatan, perawatan, dan isolasi penderita, termasuk tindakan karantina; (c). pencegahan dan pengebalan; (d). pemusnahan penyebab penyakit; (e). Penanganan Jenazah Akibat Wabah; (f). penyuluhan kepada masyarakat; (g). upaya penanggulangan lainnya. Dari ketentuan ini dapat kita lihat ada upaya preventif yang dilakukan dalam hal Penanggulangan wabah menular. Dan setiap upaya yang menghalangi penanganan tersebut, akan dikenakan sanksi yang tegas berupa sanksi pidana seperti yang diatur dalam pasal 14 UU Nomor 4 Tahun 1984. Sanksi Pidana yang dikenakan sebagai akibat dari adanya kejahatan ataupun pelanggaran terhadap upaya penanggulangan wabah penyakit menular.

Penguatan nilai kemanusiaan serta penegakan hukum dan Hak Asasi Manusia memiliki korelasi yang kuat dan berpengaruh satu sama lainnya. Pengauatan nilai kemanusiaan serta penegakan hukum dan Hak Asasi manusia berhubungan dengan implementasi nilai-nilai Pancasila. Seluruh ketentuan yang mengatur tentang Penegakan Hukum dan Hak Asasi Manusia mempunyai dasar acuan Pancasila. Oleh karena itu, instrumen penegakan hukum adalah menjadi hal yang utama dalam penguatan nilai Pancasila. Instrumen Penegakan Hukum menjamin tegaknya nilai kemanusiaan, dan nilai kemanusiaan juga digunakan dalam Penegakan hukum yang berlandaskan keadilan. Apabila terjadi Tindakan penolakan pemakaman jenazah korban Covid-19, maka aparat penegak hukum haruslah melakukan penegakan hukum yang tegas dan adil untuk menjamin tegaknya nilai kemanusiaan dan Hukum dan Hak Asasi manusia. Apalagi untuk jenazah

$44 \mid$ Penegakan hukum dan hak asasi manusia... Manihuruk, Marthin Fransisco 
yang disebabkan karena wabah sudah diatur dalam hukum positif dan mempunyai sanksi pidana (medanbisnisdaily.com).

Undang-undang Penyakit wabah menular memberikan sanksi pidana apabila terjadi upaya yang menghalangi pelaksanaan penanggulangan penyakit wabah menular. Penerapan sanksi pidana tentu ditujukan untuk memberikan efek jera bagi pelaku yang menghalangi pelaksanaan penanggulangan wabah penyakit, sehingga pelaksanaan penanggulangan wabah dapat berjalan dengan efektif. Hukum Pidana merupakan hukum yang bersifat publik sehingga mengatur hal-hal yang berkaitan dengan publik. Penegakan hukum dengan mekanisme hukum pidana harus dilakukan dengan memperhatikan asas-asas hukum pidana dan tujuan hukum pidana. Beberapa Asas-asas hukum pidana seperti asas legalitas, asas hukum nullum delictum noela poena sine praevia lege, asas terotorial, asas perlindungan (asas nasional pasif), asas personal ( Nasional aktif), asas universal (Prasetyo, 2012: 37-46), bertujuan untuk menjamin adanya kepastian hukum dan mencegah terjadinya tindakan-tindakan yang lain yang tidak sesuai dengan ketentuanketentuan yang ada dalam perundang-udnangan khusnya pada ranah hukum pidana. Jika dilihat di dalam Rancangan KUHP Juli Tahun 2006, tujuan Pemidanaan ditentukan dalam pasal 51 yaitu pemidanaan bertujuan untuk (Prasetyo, 2012:14):

1. Mencegah dilakukannya tindak pidana dengan menegakkan norma hukum demi pengayoman masyarakat

2. Memasyarakatkan terpidana dengan mengadakan pembinaan sehingga menjadi orang yang baik dan berguna

3. Menyelesaikan konflik yang ditimbulkan oleh tindak pidana, memulihkan keseimbangan, dan mendatangkan rasa damai di dalam masyarakat; dan

4. Membebaskan rasa bersalah pada terpidana.

Penegakan Hukum dengan mekanisme hukum pidana, tentunya bertujuan utnuk menegakkan Hak Asasi Manusia seperti yang tercantum di dalam Undang-udanng Nomor 39 tahun 1999 tentang Hak Asasi Manusia dan Deklarasi Universal HAM. Selain itu juga bertujuan untuk menegakkan hakhak sipil dari setiap masyarakat. Penegakan hukum ini bertujuan untuk menegakkan Hak-hak dasar yang dimiliki setiap manusia. Jika dikaitkan dengan penolakan jenazah Covid-19 tersebut maka jelas melanggar hak-hak dasar manusia. Pelanggaran Hak Asasi Manusia dikelompokkan menjadi 2 bentuk yaitu, pelanggaran HAM berat meliputi kejahatan Genosida dan kejahatan kemanusiaan. Pelanggaran Ham ringan meliputi penganiayaan, pemukulan, dan mencemarkan nama baik seseorang (Suparyanto, 2019:17). Jika dilihat dari bentuk pelanggarannya, maka pelanggaran ini termasuk pelanggaran Hak Asasi Manusia Ringan. Walaupun demikian, Pelanggaran Hak Asasi Manusia baik yang berat atapun ringan, tetap akan dikulifikasi sebagai pelanggaran HAM apabila telah merampas Hak-hak dasar manusia. Pelanggaran HAM dapat terjadi karena 2 faktor yaitu faktor Internal dan Eksternal. Faktor Internal meliputi : rendahnya tingkat kesadaran terhadap HAM, Rendahnya sikap toleransi, sikap egois dan mementingkan diri sendiri, rendahnya pengetahuan tentang HAM. Sedangkan Faktor Eksternal adalah

45 | Penegakan hukum dan hak asasi manusia.. Manihuruk, Marthin Fransisco

Jurnal Christian Humanioran | http://e-journal.iakntarutung.ac.id/index.php/humaniora 
kesenjangan sosial ekonomi yang tinggi, ketidaktegasan aparat penegak hukum, penyalahgunaan kekuasaan, teknologi yang disalahgunakan (Suparyanto, 2019: 20 - 24).

Selain terdapat di dalam deklarasi Universal Ham dan Undang-undang Nomor 39 tahun 1999, Pasal 16 Kovenan Internasional untuk Hak-hak sipil dan Politik (International Covenant on Civil and Political Rights) mengatakan bahwa setiap orang berhak untuk diakui sebagai pribadi dihadapan hukum dimanapun ia berada (International Covenant On Civil and Political Rights, Pasal 16). Hak setiap orang diakui sebagai pribadi di depan hukum berarti setiap orang itu diakui haknya oleh hukum dan dilindungi sebagai subjek hukum. Manusia adalah subjek hukum yang mempunyai hak dan kewajiban. Manusia sebagai subjek hukum jika dilihat dalam hukum perdata diakui sejak ia dilahirkan ataupun masih di dalam kandungan sampai ia meninggal. Dari sini dapat kita lihat bahwa manusia yang ketika dia meninggal pun mempunyai hak untuk diperlakukan layak.

Jika Penolakan Pemakaman Jenazah korban Covid-19 dilihat dari persamaan kedudukan di dalam hukum dan perlindungan hukum, maka dapat dilihat bahwa di dalam Pasal 26 Kovenan Internasional Untuk Hak-hak sipil dan Politik mengatakan bahwa semua orang berkedudukan sama dihadapan hukum dan berhak atas perlindungan hukum yang sama tanpa diskriminasi apapun. Dalam hal ini hukum harus melarang diskrimanasi apapun, dan menjamin perlindungan yang sama dan efektif bagi semua orang terhadap diskriminasi atas dasar apapun seperti ras, warna, jenis kelamin, bahasa, agama, politik atau pendapat lain, asal-usul kebangsaan atau sosial, kekayaan, kelahiran atau status lain (International Covenant On Civil and Political Rights). Sehingga dari sini dapat kita lihat bahwa, tidak ada alasan diskriminasi apapun terhadap manusia. Pada pasal ini, diakui bahwa ada "status lain" yang tidak dapat dijadikan dasar untuk melakukan tindakan yang tidak sesuai dengan kemanusiaan dan juga diskriminasi. Sehingga dalam hal ini dapat kita lihat bahwa Tindakan Penolakan Pemakaman jenazah korban Covid-19 itu adalah merupakan perbuatan yang bertantangan dengan peraturan Perundang-undangan.

\section{Penegakan Hukum dan Hak Asasi Manusia dengan Paradigma Pancasila}

Pancasila memiliki keluasan seluas alam pikiran filsafat bangsa Indonesaia, dan mempunyai kedalaman pengertian sedalam jiwa dan hasrat yang sedalam-dalamnya dari bangsa Indonesia itu sendiri (Riyanto, 2015:4). Bangsa Indonesia merupakan bangsa yang multikulturalisme. Konsep Multikulturalisme tidak dapat begitu saja disamakan dengan konsep keanekaragaman suku bangsa atau kebudayaan yang menjadi ciri masyarakat majemuk. Multikulturalisme menekankan keanekaragaman kebudayaan dalam kesederajatan (Dewantara, 2017: 148). Sebuah masyarakat di dalamnya terdapat individu-individu yang saling berhubungan satu sama lain. Hubungan antara individu dengan individu maupun individu dengan masyarakat dituntut adanya pengorbanan dan pengabdian agar tercipa keseimbangan antara individu dengan masyarakat (Muhammad, 2011:165). Maka harus ada kesadaran yang dimiliki manusia untuk memecahkan masalah kemanusiaan

46 | Penegakan hukum dan hak asasi manusia... Manihuruk, Marthin Fransisco 
dan masalah sosial. Masalah kemanusiaan, misalnya korban bencana alam, korban perang, bahaya kelaparan, wabah penyakit menular, dan masalah pengungsi. Masalah sosial, misalnya wanita tuna susila, gelandangan dan pengemis, anak telantar, anak yatim piatu, kesemrawutan lalu lintas, serta pekerjaan dan upah layak (Muhammad, 2011:165). Masyarakat juga dikatakan sebagai satu sistem sosial yang terdiri dari Individu-individu atau kelompok-kelompok yang berinteraksi secara harmonis (Dewantara, 2017: 128).

Perubahan sosial yang terjadi di dalam masyarakat adalah sebuah kepastian. Perubahan sosial ditengah-tengah relasi sosial akan mempengaruhi pandangan-pandangan terhadap individu-individu yang adal di dalam masyarakat. Perubahan sosial dapat dilihat ketika perubahan tersebut dapat mempengaruhi kehidupan manusia secara luas. Perubahan sosial dapat berpengaruh positif jika mampu memperbaiki tingkat kehidupan manusia dan dapat berpengaruh negatif jika menyebabkan disorganisasi sosial (Purwasih \& Sri, 2018:4). Maka setiap tindakan yang dilakukan oleh masyarakat Indonesia dalam kehidupan berbangsa, bermasayrakat dan bernegara, haruslah sesuai dengan nilai-nilai Pancasila, Agar nilai-nilai Pancasila dapat mempengaruhi kehidupan masyarakat Indonesia. Pancasila dibuat berdasarkan nilai-nilai yang telah hidup di dalam masyarakat. Sehingga dalam mencapai sebuah tujuan, masyarakat mempunyai landasan yang sama yaitu Pancasila sebagai Ideologi Negara. Fungsi sebuah Ideologi bisa dilihat dari peran dan kedudukannnya dalam suatu masyarakat atau sebuah negara. Setiap masyarakat mempunyai sistem nilai yang harus disepakati dan diterapkan bersama. Kehidupan masyarakat yang jauh dari tatanan nilai akan menimbulkan ketidaktertiban dan ketidaknyamanan (Djaja, 2009:5).

Penanganan pemakaman jenazah korban Covid-19 selain memperhatikan aspek kesehatan, juga memperhatikan nilai-nilai kemanusiaan. Pada aspek Kesehatan, Penanganan Pemakaman Jenazah sudah diatur dalam Protokol. Pemerintah menetapkan dan menerapkan protokol kesehatan untuk mencegah terjadinya penularan kepada masyarakat. Hal-hal yang diatur di dalam Protokol tersebut sudah sesuai dengan standar WHO. Pengaturan yang ada di dalam protokol tersebut misalnya mengatur tentang penyiapan dan pembungkusan jenazah dari luar RS sebelum dipindahkan ke pemulasaran jenazah di fasyankes, penyiapan dan pembungkusan jenazah dari dalam RS sebelum dipindahkan ke ruang pemulasaran jenazah, proses dekontaminasi jenazah saat tiba di ruang pemulasaran jenazah, proses memandikan jenazah, Desinfeksi dan kebersihan lingkungan, persemayaman, shalat jenazah, pemakaman (Protokol Pencegahan Penularan Covid-19 dan Perlindungan Masyarakat Penanganan Jenazah Covid-19 atau Jenazah PDP yang menunggu Hasil Lab RT-PCR diakses dari https://covid19.go.id/storage/app/media/Protokol/Protokol\%20Pencegahan\%2 0Penularan\%20Covid9\%20dan\%20Perlindungan\%20Masyarakat\%20Penang anan\%20Jenazah.pdf).

Menurut Kamus Besar Bahasa Indonesia ( KBBI) Protokol adalah surat-surat resmi yang memuat hasil perundingan (persetujuan dan 
sebagainya). Protokol memang bukan suatu produk perundang-undangan. Akan tetapi protokol merupakan suatu produk yang seharunya dipatuhi bersama karena protokol dibuat untuk melakukan pencegahan. Alasan dibuatnya protokol salah satunya dengan pertimbangan memperhatikan martabat, budaya, dan agama jenazah dan keluarganya yang tetap harus dilindungi dan dihormati (https://covid19.go.id/storage/app/media/Protokol/Protokol\%20Pencegahan\% 20Penularan\%20Covid19\%20dan\%20Perlindungan\%20Masyarakat\%20Pena nganan\%20Jenazah.pdf.). Sehingga dalam hal Penanganan Jenazah korban Covid-19 ini harus memperhatikan nilai-nilai kemanusiaa. Nilai kemanusiaan yang pada dasarnya terdapat di dalam Pancasila seperti yang tercantum dalam Pancasila yaitu sila ke-2 merupakan nilai yang Universal. Sila ke 2 yaitu "Kemanusiaan yang Adil dan Beradab", menekankan kepada kita bahwa nilai kemanusiaan adalah nilai yang fundamental yang dimiliki oleh setiap manusia dan setiap manusia harus mendapatkan perlakuan secara adil. Pihak keluarga korban meninggal yang diakibatkan Covid-19, berhak mendapatkan keadilan. Termasuk keadilan penanganan jenazah keluarganya yang meninggal karena Covid-19. Keadilan ini pun diterjemahkan ke dalam setiap peraturan perundang-undangan dan juga Protokol Kesehatan yang ditetapkan pemerintah. Nilai-nilai Pancasila menjadi acuan dalam pembentukan peraturan yang ada di Indonesia. Sehingga, seharusnya tidak boleh ada tindaka Penolakan yang dilakukan oleh Individu ataupun kelompok yang mengatasnamakan masyarakat terhadap pemakaman jenazah Covid-19.

Penegakan hukum dan Hak Asasi Manusia dengan Paradigma Pancasila menekankan bahwa pelaksanaan Penegakan Hukum dan Hak Asasi Manusia itu berdasarkan Pancasila. Pancasila sebagai sistem filsafat mempunyai nilai-nilai Pancasila yang mengandung unsur berfikir filsafat. Karena itu Pancasila dikatakan sebagai sistem Filsafat. Sebagai sistem filsafat, Pancasila telah memenuh ciri-ciri berfikir filsafat yaitu: (1). Koheren yang berarti berhubungan satu sama lain; (2). Bersifat menyeluruh yang berarti mencakup segala hal dan gejala yang terdapat dalam kehidupan manusia; (3). Harus bersifat mendasar artinya bentuk perenungan mendalam yang sampai ke inti mutlak permasalahan sehingga menemukan aspek yang sangat fundamental; (4). Bersifat spekulatif yang berarti buah pikir hasil perenungan sebagai praanggapan yang menjadi titik awal yang menjadi pola dasar berdasarkan penalaran logis (Kementerian Riset, Teknologi dan Pendidikan Tinggi Direktorat Pembelajaran Mahasiswa, 2016:144). Sehingga dalam hal ini aturan-aturan yang menjadi dasar penegakan Hukum dan Hak Asasi Manusia haruslah sesuai dengan Filsafat Pancasila. Peraturan-peraturan yang dibuat dengan dasar Pancasila, harus menyentuh segala aspek kehidupan Pancasila. Nilai-nilai yang terdapat di dalam Pancasila merupakan nilai yang sifatnya Universal yang menyentuh seluruh kehidupan bermasyarakat, berbangsa dan bernegara. Nilai-nilai yang terkandung dalam peraturan perundang-undangan haruslah menyentuh aspek yang fundamental dari kehidupan masyarakat. Sehingga aturaan-aturan yang diturunkan dari Pancasila, bisa dilaksanakan dengan mengedepankan nilai Pancasila dan sesuai dengan tujuan hukum. Sebagaimana yang dikatakan Gustav Radbruch, 
bahwa tujuan hukum ada 3 yaitu, keadilan, kepastian dan kemanfaatan. Keadilan adalah merupakan hal yang paling utama dalam menegakkan hukum. Khusus Keadilan, maka akan ditemukan 3 macam keadilan yaitu (Muhammad, 2018: 181 - 183):

1. Keadilan Kooordinatif : terjadi dalam hubungan antara sesama anggota masyarakat ( anggota kelompok). Dalam hubungan tersebut, kedudukan pihak-pihak setara, sejajar, dan tidak melebihi satu sama lain

2. Keadilan Subordinatif : terjadi dalam hubungan rakyat dengan penguasa atau warga negara dengan pemerintah atau anggota kelompok dengan pemimpin.

3. Keadilan Superordinatif : terjadi dalam hubungan penguasa dengan rakyat, atau pemerintah dengan warga negara, atau pemimpin dengan anggota yang dipimpin.

Dasar pertimbangan yang dicantumkan dalam protokol, melihat martabat dari jenazah dan keluarga korban Covid-19. Artinya bahwa ada hakhak asasi manusia yang harus diakui. Sehingga kemanusiaan adalah hal yang mutlak. Sila ke-2 "kemanussiaaan yang adil dan berada" memberi konsekuensi di bidang penyelenggaraan negara yaitu bahwa negara c.q. pemerintah berkewajiban untuk menjamin dan melindungi hak-hak asasi warga negara Indonesia (Bambang Suteng Sulasmono, 2015:126). Prinsip Persaudaraan Universal menurut sila kemanusiaan yang memberi keseimbangan antara pemenuhan hak individu dan hak sosial ( kolektif), menjadi landasan untuk membangun negara-bangsa yang humanis. Dengan Prinsip kesamaaan kemanusiaan yang adil dan beradab, komitmen kemanusiaan dan ikatan perdsaudaraan bangsa Indonesia menembus batasanbatasan lokal, nasional, atau regional, menjangkau persaudaraan antarmanusia dan antarbangsa secara global (Yudi Latif, 2011: 242 ).

Bung Hatta dalam Yudi Latif memandang sila kedua pancasila memiliki konsekuensi ke dalam dan keluar. Ke dalam, menjadi pedoman negara untuk memuliakan nilai-nilai kemanusiaan dan hak dasar/asasi manusia dengan menjalankan fungsi “ melindungi segenap bangsa Indonesia dan seluruh tumpah darah Indonesia, memajukan kesejahteraan umum, mencerdaskan kehidupan bangsa. Keluar menjadi pedoman politik luar negeri bebas aktif dalam rangka " ikut serta melaksanakan ketertiban dunia yang berdasarkan kemerdekaan, perdamaian abadi dan keadilan sosial (Yudi Latif, 2011: 241 ). Sehingga dalam hal ini, jenazah dan keluarga korban Covid-19 harus mendapatkan perlindungan Hak asasi/hak dasar manusia. Jika melihat pada Deklarasi Universal Hak Asasi Manusia, Perlindungan terhadap Jenazah dan keluarga korban Covid-19 ini pun dikuatkan di dalam Pasal 6 Deklarasi Universal Hak Asasi Manusia yang menyebutkan bahwa setiap orang berhak atas pengakuan di depan hukum sebagai manusia pribadi dimana saja ia berada. Sehingga jenazah dan keluarga mempunyai persamaan di dalam hukum yang berkaitan menyangkut dengan hak-hak asasi manusia dan martabat kemanusiaan. Implementasi terhadap penegakan Hak Asasi manusia dan martabat manusia akan menimbulkan rasa keadilan bagi keluarga jenazah Covid-19. Perlakuan adil ada apabila dihubungkan dengan koderat manusia

49 | Penegakan hukum dan hak asasi manusia.. Manihuruk, Marthin Fransisco

Jurnal Christian Humanioran | http://e-journal.iakntarutung.ac.id/index.php/humaniora 
sebagai makhluk sosial (zoon Politicon) yang harus hidup bermasyarakat. Dalam kehidupan bermasyarakat, manusia mempunyai berbagai macam kebutuhan yang hanya dapat dipenuhi dengan sempurna apabila berhubungan dengan manusia lain dalam masyarakat atau alam lingkungan (Muhammad, 2011:176).

Masalah utama yang terdapat di masyarakat adalah masih banyak masyarakat (baik Individu, maupun kelompok) tidak memahami aturan-aturan yang berlaku di Indonesia yang bertujuan untuk mencegah terjadinya penularan penyakit. Aturan-aturan yang dibuat oleh pemerintah, dibentuk dengan mengedepankan nilai-nilai Pancasila sebagai Pandangan hidup bangsa Indonesia dijadikan pegangan dalam bertindak dalam kehidupan berbangsa, bermasyarakat dan bernegara. Pancasila memiliki 3 dimensi yaitu dimensi realitas, dimensi idealitas dan dimensi fleksibilitas. Setiap elemen Masayrakat harus memahami bahwa pengertian Dimensi Realitas Pancasila sebagai Ideologi Negara adalah nilai-nilai pancasila bersumber dari nilai-nilai kehidupan bangsa Indonesia (Kementerian Riset, Teknologi dan Pendidikan Tinggi Direktorat Pembelajaran Mahasiswa). Nilai-nilai yang telah hidup dalam masyarakat Indonesia diwujudkan dalam sebuah pancasila yang semua silanya saling berhubungan satu sama lain. Hubungan antarsila dalam Pancasila merupakan rangkaian utuh, yang saling menjiwai, dan memiliki hubungan hierarkis atau tidak bisa diacak susunannya (Djaja, 2009:64).

Apabila penegak hukum sudah melakukan penegakan hukum terhadap pelaku yang melakukan Tindakan penolakan Pemakaman Jenazah Covid-19, maka seharusnya, pemulihan hak terhadap korban dari tindak tersbut dipulihkan. Pasal 8 Deklarasi Universal Hak Asasi Manusia menyebutkan bahwa setiap orang berhask atas pemulihan yang efektif dari penagdilan nasional yang kompeten untuk tindakan-tindakan yang melanggar hak-hak dasar yang diberikan kepadanya oleh undang-undang dasar atau hukum. Hal ini tentunya untuk memberikan perlindungan hukum terhadap keluarga korban jenazah korban Covid-19. Selain itu, upaya dalam sosialisasi nilainilai kemanusiaan yang terdapat dalam Pancasila adalah merupakan tugas yang utama dalam hal mencegah terjadinya tindakan-tindakan diluar batas kemanusiaan.

\section{KESIMPULAN DAN SARAN}

\section{Kesimpulan}

1. Penegakan Hukum dan Hak Asasi Manusia pada tindakan penolakan pemakaman Jenazah korban Covid-19 harus dilakukan secara komprehensif dengan memperhatikan kaidah-kaidah hukum yang berlaku dan memberikan rasa keadilan. Tindakan penolakan pemakaman Jenazah korban Covid - 19 bertentangan dengan Hukum dan Hak Asasi Manusia. Hukum positif telah mengatur tentang tata cara penanganan wabah penyakit menular. Selain itu, bertentangan dengan Hak Asasi manusia sebagaimana telah diatur di dalam Undang-undang Nomor 39 Tahun 1999, Deklarasi Universal Hak Asasi Manusia dan International Covenant on Civil and Political Rights ( ICCPR) yang telah diratifikasi melalui Undang-undang Nomor 12 Tahun 2005. 
2. Penolakan pemakaman jenazah korban Covid - 19 ini tidak sesuai dengan penegakan Hukum dan Hak Asasi Manusia dengan Paradigma Pancasila. Pancasila merupakan dasar dari segala peraturan perundang-undangan yang ada di Indonesia. Undang-udang nomor 4 Tahun 1984 tentang Wabah Penyakit Menular merupakan bentuk Implementasi dari Pancasila khususnya sila Ke-2 yaitu " Kemanusiaan Yang Adil dan Beradab". Nilai Pancasila adalah nilai yang universal yang diturunkan ke dalam bentuk perturan perundang-undangan. Undang-undang tentang Hak Asasi Manusia, Undang-undang tentang Penyakit Wabah menular, maupun protokol kesehatan yang berkaitan dengan Pencegahan dan Penanganan Jenazah Covid-19 disusun dengan memasukkan niali-nilai Pancasila di dalamnya. Oleh karena itu, aturan yang dibuat dalam hal pelaksanaan penanganan Wabah, tidak boleh dilanggar. Apabila telah terjadi pelanggaran, maka kewajiban negara untuk memulihkan hak-hak dasar daripada keluarga jenazah korban Covid-19

\section{Saran}

1. Setiap tindakan penolakan pemakaman Jenazah korban Covid - 19 yang tidak memiliki dasar ketentuan di dalam peraturan perundang-undangan, haruslah di klasifikasikan sebagai tindak pidana yang menghalangi upaya penanggulangan wabah Covid -19. Maka dengan demikian harus dilakukan Penegakan hukum yang sesuai dengan ketentuan perundangundangan yang berlaku untuk memberikan efek jera bagi oknum yang melakukan nya. Hal ini ditujukan untuk meminimalisir tindakan-tindakan penolakan jenazah korban Covid - 19 lainnya

2. Perlu penguatan nilai-nilai Pancasila kepada masyarakat, khususnya sila Ke-2. Hal ini ditujukan karena terjadi krisis kemanusiaan yang ada pada masyarakat yang menolak pemakaman jenazah korban Covid - 19 tersebut. Penguatan nilai-nilai ini tentunya harus dilakukan secara komprehensif. Penegakan hukum, pendidikan secara Formal maupun tidak Formal, harus dilakukan untuk mencegah terjadinya kejadiankejadian penolakan jenazah Covid -19. Penguatan nilai-nilai Pancasila ini haruslah disertai dengan penegakan hukum yang tegas oleh para aparatur penegak hukum.

\section{DAFTAR PUSATAKA}

Armada Riyanto, dkk. Kearifan Lokal - Pancasila Butir-butir Filsafat keindonesiaan. Yogyakarta: Kanisius, 2015.

Budiardjo, Miriam. Dasar-dasar Ilmu Politik. Jakarta: Gramedia Pustaka Utama, 2008.

Dewantara, Agustinus W. Diskursus Filsafat Pancasila Dewasa Ini. Yogyakarta: Kanisius, 2017.

51 | Penegakan hukum dan hak asasi manusia.. Manihuruk, Marthin Fransisco Jurnal Christian Humanioran | http://e-journal.iakntarutung.ac.id/index.php/humaniora 
Djaja, Wahjudi. PANCASILA diantara Ideologi Besar Dunia. Klaten: Cempaka Putih, 2009.

Fuady, Munir. Aliran Hukum Kritis Paradigma Ketidakberdayaan Hukum. Bandung: Citra Aditya Bakti, 2018.

Ibrahim, Jonaedi Effendi \& Johnny. Metode Penelitian Hukum Normatif dan Empiris. Jakarta: Kencana, 2016.

Kemernterian Riset, Teknologi dan Pendidikan Tinggi. Pendidikan Pancasila

Untuk Perguruan Tinggi. Direktorat Pembelajaran Mahasiswa, 2016.

Kusumantoro, Sri Muhammad. Sosiologi Sebagai Ilmu. Klaten: Cempaka Putih, 2019.

Latif, Yudi. Negara Paripurna. Jakarta: Gramedia Pustaka Utama, 2011.

Muhammad, Abdulkadir. Ilmu Sosial Budaya Dasar. Bandung: Citra Aditya Bakti, 2011.

Prasetyo, Teguh. Hukum Pidana. Jakarta: Kencana, 2012.

Purwasih, Joan Hesti Gita, and Sri Muhammad Kusmantoro. Perubahan Sosial. Klaten: Cempaka Putih, 2018.

Sulasmono, Bambang Suteng. Dasar Negara Pancasila. Yogyakarta: Kanisius, 2015.

Suparyanto, Yudi. Deklarasi HAM di Indonesia. Klaten: Cempaka Putih, 2019.

www.medanbisnisdaily.com/news/online/read/2020/04/16/105759/penolakan jenazah_covid_19_kemanusiaan_hukum_dan_pancasila/

Undang-undang Nomor 39 Tahun 1999 tentang Hak Asasi Manusia Undang-undang Nomor 4 Tahun 1984 tentang Wabah Penyakit Menular Deklarasi Universal Hak Asasi Manusia International Covenant on Civil and Political Rights 